\title{
Phytochemical variability during vegetation of Chamerion angustifolium (L.) Holub genotypes derived from in vitro cultures
}

\author{
Mariola Dreger $^{1}$ (I) $\cdot$ Katarzyna Seidler-Łożykowska $^{2} \cdot$ Milena Szalata $^{1} \cdot$ Artur Adamczak $^{2} \cdot$ Karolina Wielgus $^{1}$
}

Received: 26 March 2021 / Accepted: 9 August 2021 / Published online: 21 August 2021

(c) The Author(s) 2021

\begin{abstract}
The purpose of the study was to evaluate Chamerion angustifolium (L.) Holub genotypes for preliminary selection and further breeding programs aimed at obtaining a suitable industrial form for the pharmaceutical applications. Clonally propagated plants representing 10 genotypes of Ch. angustifolium were regenerated under in vitro conditions, hardened and planted in the field. Studies included an evaluation of shoot proliferation, phytochemical assessment of in vitro and ex vitro plants as well as investigations of intraspecies variability regarding four phenological stages: vegetative, beginning of blooming, full blooming, and green fruit phases. Quantitative and qualitative analyses of bioactive compounds were performed using highperformance liquid chromatography coupled with diode array detector and tandem mass spectrometer (HPLC-DAD-MS/ MS) and high-performance liquid chromatography (HPLC) methods. The efficiency of shoot multiplication varied between genotypes from 8.12 to 21.48 shoots per explant. A high reproduction rate ( $>20$ shoots per explant) was recorded for four lines (PL_45, PL_44, PL_58, DE_2). Plants grown in vitro synthesized oenothein B $\left(11.2-22.3 \mathrm{mg} \mathrm{g}^{-1} \mathrm{DW}\right)$ and caffeic acid derivatives. Plants harvested from field contained the full spectrum of polyphenols characteristic for this species, and oenothein $\mathrm{B}$ and quercetin 3-O-glucuronide were the most abundant. The maximal content of oenothein B was determined in the vegetative phase of fireweed, while some flavonoids were found in the highest amount in full blooming phase. The results of analysis of variance indicated significant differences among genotypes in oenothein $\mathrm{B}, 3$ - $O$-caffeoylquinic acid and flavonoids accumulation in four phenological phases. PL_44 plants were characterized by high content of oenothein B and quercetin 3-O-glucuronide as well as a relatively high level of other flavonoids. Based on our phytochemical and micropropagation studies, PL_44 genotype was the best candidate for early selection and further breeding programs.
\end{abstract}

\section{Key Message}

Epilobium angustifolium genotypes differ in the shoot multiplication efficiency. Significant genotypic variation among tested genotypes was found in flavonoids, oenothein B and chlorogenic acid level in four developmental phases.

Keywords Epilobium angustifolium · Fireweed · HPLC-DAD-MS/MS · Oenothein B · Genotypes · Phenological phases

Communicated by Amita Bhattacharya.

Mariola Dreger

mariola.dreger@iwnirz.pl

Katarzyna Seidler-Łożykowska

katarzyna.lozykowska@iwnirz.pl

Milena Szalata

milena.szalata@iwnirz.pl

Artur Adamczak

artur.adamczak@iwnirz.pl
Karolina Wielgus

karolina.wielgus@iwnirz.pl

1 Department of Biotechnology, Institute of Natural Fibres and Medicinal Plants National Research Institute, Wojska Polskiego 71B, 60-630 Poznan, Poland

2 Department of Breeding and Botany of Useful Plants, Institute of Natural Fibres and Medicinal Plants National Research Institute, Kolejowa 2, 62-064 Plewiska, Poland 


\section{Introduction}

Fireweed (Chamerion angustifolium /L./ Holub, syn. Epilobium angustifolium L.) is an important medicinal plant from the Onagraceae family. The species is native to the Northern Hemisphere and common to most areas of Europe, Asia and North America (Wagner et al. 2007). It usually grows up to $2 \mathrm{~m}$ high and develops inflorescences with pink flowers from June to September. Fireweed herb has been used in European folk medicine to treat wounds, skin diseases, stomach disorders, liver and prostate gland inflammation as well as kidney and urinary tract diseases (Adamczak et al. 2019; Sõukand et al. 2020). In Russia and in some countries of Eastern Europe, an infusion prepared from its fermented leaves (Koporye tea or Ivan Chai) is consumed as tea (Kalle et al. 2020).

In the last decade, species from the Epilobium genus have received great interest in research, which documented the anti-androgenic, analgesic, antioxidant, antimicrobial, anti-inflammatory and anticancer effects of extracts in numerous preclinical studies, reviewed by Granica et al. (2014), Schepetkin et al. (2016), Vitalone and Allkanjari (2018). The European Medicines Agency (EMA) stated that E. angustifolium and E. parviflorum can be used as traditional herbal medicinal products for treatment and alleviating symptoms related to benign prostatic hyperplasia, BPH (European Medicines Agency 2015). Though almost all authors emphasize the need for evaluating safety and efficacy in the clinical studies, they also agree that Ch. angustifolium extracts have a positive effect on $\mathrm{BPH}$ (Vitalone and Allkanjari 2018; Deng et al. 2019). Recently published results of a double-blind, placebo-controlled clinical trial confirmed beneficial effect of fireweed extract in alleviating BPH symptoms (Esposito et al. 2021).

Medicinal properties of $C h$. angustifolium have been attributed to the synergic effect of polyphenols. Over 200 constituents have been identified in fireweed plants: flavonoids, phenolic acids, tannins and other minor constituents such as sterols, triterpenoids, fatty acids, and essential oil (Adamczak et al. 2019). Oenothein B is the most abundant ellagitannin, whose content ranges up to $50 \%$ of the total mass of oligomeric ellagitannins (Baert et al. 2015). This compound is considered to be the main bioactive phytochemical, which showed anti-androgenic, apoptotic, antioxidant and anti-inflammatory properties documented in in vitro and in vivo tests (Yoshida et al. 2018). Apart from ellagitannins, more than 50 flavonoids and their derivatives were identified in Ch. angustifolium (Adamczak et al. 2019). Fireweed has a flavonoid content of about $1-2 \%$, mainly the aglycones of quercetin, myricetin and kaempferol (Hevesi Tóth et al. 2009; Monschein et al. 2015). Antioxidant and anti-inflammatory properties of fireweed are closely related to this group of compounds. Myricetin 3-O-glucuronide was more potent than indomethacin in the rat paw edema test (Hiermann et al. 1998) and showed an inhibitory effect on prostaglandin biosynthesis (Hiermann et al. 1991). Quercetin 3-O-glucuronide (miquelianin) is the most abundant flavonoid of Ch. angustifolium (Hevesi Tóth et al. 2009; Schepetkin et al. 2016), which has therapeutic potential in neurodegenerative diseases (Ishisaka et al. 2014; Baral et al. 2017). Oenothein B and quercetin 3-O-glucuronide were proposed for use as markers for a raw material standardization (Kiss et al. 2011). A great variety of phenolic acids, including 26 substances (e.g., caffeic, ellagic, ferulic, gallic, protocatechuic acids and caffeoylquinic acid isomers), was found in Ch. angustifolium plants (Deng et al. 2018; Gryszczyńska et al. 2018). Phenolic acids and their derivatives are significant contributors to the antioxidant and therapeutic potential of fireweed against BPH (Deng et al. 2019).

Although fireweed is a popular medicinal plant in Central and Eastern Europe, no forms or varieties have been yet developed for pharmaceutical purposes. Obtaining a new variety using traditional methods is a time-consuming process that lasts even decades. In vitro cultures and micropropagation techniques give many advantages over conventional propagation such as: high efficiency, rapid multiplication, large scale production, lack of environmental restrictions (e.g., exposure to pathogens and pests). Hence, they can be useful in reproduction of valuable genotypes for breeding purposes.

Diversity among germplasm collections is essential for selection of superior genotypes and success of any improvement in breeding programs. Despite strong interest in fireweed's polyphenols, little is known about intraspecies variability of Ch. angustifolium. Seasonal variation (Jürgenson et al. 2012; Maruška et al. 2014) as well as inter-population and inter-organ distribution of some polyphenols of this species (Baert et al. 2017) were reported earlier, but there are no information about the phytochemical variability between individual genotypes of fireweed. In addition, there are only a few works reporting in vitro culture of $C h$. angustifolium (Turker et al. 2008; Dreger et al. 2016, 2020).

In our study, genetically uniform specimens of Ch. angustifolium were regenerated under in vitro conditions, hardened and planted in the field. Micropropagated plants were used as the reproductive material providing homogeneous and sufficient raw material from each of 10 accessions for the study on genotypic and developmental variation. The assessment of the multiplication efficiency allowed the selection of genotypes suitable for mass production. In turn, evaluation of phytochemical composition of plant raw material provided insight into the seasonal accumulation of the main phenolics of fireweed and was helpful in the selection of genotypes with the high content of bioactive 
compounds. To our best knowledge, this is the first report to describe the variation between individual genotypes of Ch. angustifolium. The results of this study are part of a project in which in vitro cultures were used for the first time to obtain fireweed raw material for the pilot production of a dietary supplement used in BPH prevention. The results of the current study will be used in further breeding programs aimed to obtain an industrial form of fireweed suitable for pharmaceutical and food applications.

The aim of the present study was an evaluation of the micropropagation efficiency of $C h$. angustifolium genotypes, qualitative and quantitative analysis of polyphenolic compounds in plants cultivated under in vitro and ex vitro conditions, as well as determination of the effect of genotype and phenological stages on accumulation of the main bioactive compounds.

\section{Material and methods}

\section{Establishment of in vitro cultures and shoot proliferation}

Seeds of Ch. angustifolium were obtained from Rieger-Hofmann GmbH (Germany) and from the Garden of Medicinal Plants in Plewiska (Institute of Natural Fibres and Medicinal Plants National Research Institute, Poland, INF\&MP-NRI). The voucher specimen was deposited in the INF\&MP-NRI. In vitro cultures of fireweed were initiated as described previously (Dreger et al. 2016). The seeds were sterilized by soaking in $70 \%$ ethanol for $1 \mathrm{~min}$ and then in ACE® solution (2:1) with a drop of Tween 20 (Sigma Aldrich) for $4 \mathrm{~min}$ and washed three times in sterile water. Sterilized seeds were placed on Petri dishes with MS medium (Murashige and Skoog 1962) supplemented with $30 \mathrm{~g} \mathrm{~L}^{-1}$ sucrose and $8 \mathrm{~g} \mathrm{~L}^{-1}$ Difco Bactoagar, without plant growth regulators, and $\mathrm{pH}$ set to 5.7 prior to autoclaving at $121^{\circ} \mathrm{C}$, $105 \mathrm{kPa}$ for $20 \mathrm{~min}$. After 6 weeks of incubation at $25^{\circ} \mathrm{C}$ under the $16 / 8 \mathrm{~h}$ photoperiod (cool white fluorescent lights $25-30 \mu \mathrm{mol} \mathrm{m}{ }^{-2} \mathrm{~s}^{-1}$ ) the seedlings were a source of primary explants-roots. Roots were cut for explants $( \pm 1.0 \mathrm{~cm})$ and placed on an induction medium consisted of MS medium supplemented with 6-benzylaminopurine, $\operatorname{BAP}\left(0.1 \mathrm{mg} \mathrm{L}^{-1}\right)$, indole-3-acetic acid, IAA $\left(0.5 \mathrm{mg} \mathrm{L}^{-1}\right)$, vitamin $\mathrm{C}(0.1 \mathrm{~g}$ $\left.\mathrm{L}^{-1}\right)$, casein hydrolysate $\left(0.5 \mathrm{~g} \mathrm{~L}^{-1}\right)$, sucrose $\left(30 \mathrm{~g} \mathrm{~L}^{-1}\right)$ and agar $\left(8 \mathrm{~g} \mathrm{~L}^{-1}\right)$, and $\mathrm{pH}$ of 5.7. After four weeks multipleshoots were obtained which were further subcultured every four weeks on the same induction medium for 15 months. Multiplication and rooting proceeded at $25{ }^{\circ} \mathrm{C} \pm 2{ }^{\circ} \mathrm{C}$ and with a $16 / 8 \mathrm{~h}$ photoperiod under a photosynthetic flux of $50-60 \mu \mathrm{mol} \mathrm{m}^{-2} \mathrm{~s}^{-1}$ (daylight fluorescent tubes). To phytochemical analyses, five-week-old rooted shoots of fireweed on rooting media (bulk sample) were collected and dried at room temperature.

For the determination of genotype effect on shoot proliferation, multi-shoot cultures (Fig. 1a) derived from individual seedlings were used. The number of shoots per explant (multi-shoot) was calculated by counting individually separated shoots ( $\geq 1 \mathrm{~cm}$ length) for every 10 multishoots for each genotype. The experiment was repeated five times, which corresponded to five successive passages. The seeds and seedlings of fireweed were treated separately and marked for clear identification: a number of genotypes followed by DE for German accessions (DE_2, DE_3, DE_5, DE_6, DE_11) or PL for Polish genotypes (PL_37, PL_38, PL_44, PL_45, PL_58).

\section{Rooting, acclimatization and hardening of plants}

Shoots of Ch. angustifolium separated from multi-shoots were transferred into the vessels (Magenta GA-7 Sigma Aldrich) with a rooting medium consisting of half-strength MS medium supplemented with IAA $\left(0.5 \mathrm{mg} \mathrm{L}^{-1}\right)$, vita$\min \mathrm{C}\left(0.1 \mathrm{~g} \mathrm{~L}^{-1}\right)$, and agar $\left(8 \mathrm{~g} \mathrm{~L}^{-1}\right)$. Individual shoots $1 \mathrm{~cm}$ in length and with a minimum of three leaves were qualified as well-developed ones. The percentage of rooted plants was recorded after four weeks for 100 specimens and the counting was repeated three times. The rooted plants at age 4-7 weeks were transferred into sterile soil and perlite substrate (2:1 v/v, Kekkila Paperpot) and then acclimatized in closed tunnels in the greenhouse conditions $\left(21^{\circ} \mathrm{C}\right)$ for two weeks. After 4-5 days of transplanting, the tunnels were gradually opened and the seedlings were accustomed to lower humidity. The plants were hardening in the open tunnels at a temperature of $16^{\circ} \mathrm{C}$ for two weeks and the next two weeks in field conditions.

\section{Field cultivation}

Ch. angustifolium obtained from in vitro cultures was planted in the experimental field in Plewiska near Poznań (INF\&MP-NRI, Poland) in 2015, on a loamy soil of medium fertility. The vegetation period started in early April and lasted until the end of October. In April, greenhouse acclimatized specimens of 10 fireweed genotypes ( $\pm 15 \mathrm{~cm} \mathrm{high})$ were planted out in the field in $0.45 \times 0.25 \mathrm{~m}$ spacing. Each plot was $8.6 \mathrm{~m}^{2}$ and had about 75 plants. For each genotype, 10 plants were collected randomly at the four following phenological stages: vegetative, beginning of blooming (about $10-20 \%$ of flowers in bloom), full blooming (about $70 \%$ of flowers in bloom), and green fruit phases (Fig. 1c-f). The above-ground plant parts were dried at room temperature and used for phytochemical analyses. 


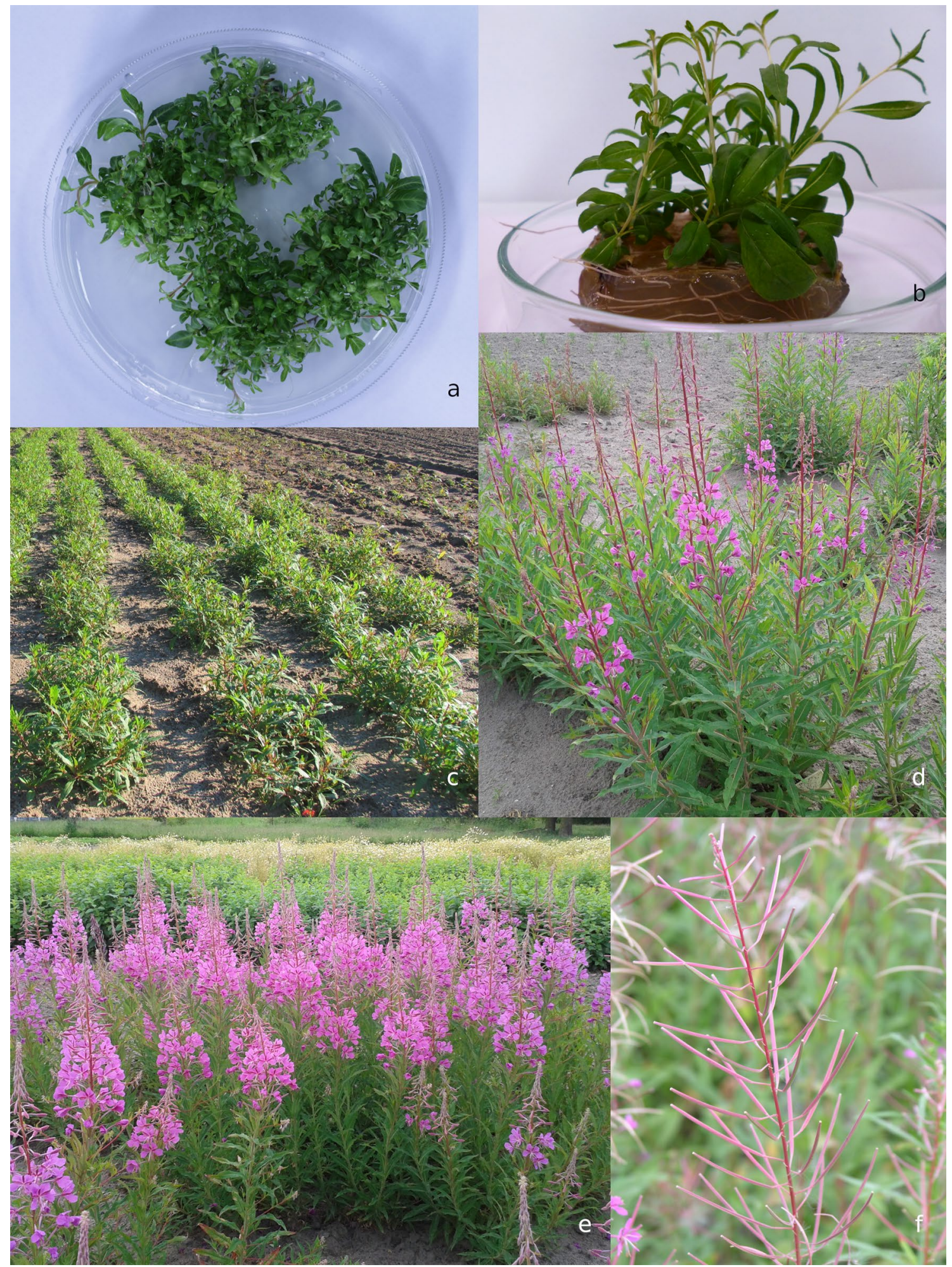

Fig. 1 Ch. angustifolium a Multi-shoots cultures, $\mathbf{b}$ In vitro rooted plants, $\mathbf{c}$ Plants in vegetative phase, $\mathbf{d}$ Beginning of blooming phase, $\mathbf{e}$ Full blooming phase, $\mathbf{f}$ Green fruit phase 


\section{HPLC-DAD-MS/MS analysis}

Qualitative analysis was performed using an HPLC system with a diode array detector, DAD (Dionex, Idstein, Germany) and an ion trap mass spectrometer (Bruker Daltonic GmbH, Bremen, Germany). Powdered plant material $(200 \mathrm{mg}$ ) was extracted (15 min) twice with 50\% methanol (v/v) at $40{ }^{\circ} \mathrm{C}$ using an ultrasonic water bath. Obtained extracts were filtered through a $0.45 \mu \mathrm{m}$ Chromafil membrane (Chromafil Xtra PET-45/25). To identify the components of the plant material, $200 \mu \mathrm{l}$ of mobile phase A was added to $800 \mu \mathrm{L}$ of the filtered extracts. The sample was mixed and qualitatively analyzed.

Separation was performed on a Zorbax $\mathrm{SB} \mathrm{C}_{18}$ column $(150 \times 2.1 \mathrm{~mm}, 1.9 \mu \mathrm{m})$ (Agilent, USA). The mobile phase consisted of deionized water/formic acid $(0.1 \% \mathrm{HCOOH})(\mathrm{A})$ and acetonitrile/formic acid $(0.1 \%$ $\mathrm{HCOOH} ; 100: 0.001 ; \mathrm{v} / \mathrm{v})(\mathrm{B})$. The gradient was: $0 \mathrm{~min}-$ $6 \% \mathrm{~B}, 60 \mathrm{~min}-28 \% \mathrm{~B}$. The column temperature was $25{ }^{\circ} \mathrm{C}$, the flow rate was $0.2 \mathrm{~mL} \mathrm{~min}{ }^{-1}$. The eluate was entered into the electrospray ionization (ESI) interface, without splitting, and compounds were analyzed in negative ion mode with the following settings: nebulizer pressure 2.8 bar; drying gas flow rate $9 \mathrm{~L} \mathrm{~min}^{-1}$, nitrogen gas temperature $300{ }^{\circ} \mathrm{C}$; capillary voltage $4.5 \mathrm{kV}$. UV spectra were recorded in the range $200-450 \mathrm{~nm}$. The presence of substances in extracts was confirmed by comparison of retention times, and UV spectra and $\mathrm{m} / \mathrm{z}$ signals with corresponding standards. Identification of oenothein $B$ and quercetin 3-O-glucuronide was complemented by applying commercially available standards.

\section{HPLC-DAD analysis}

Quantitative analysis was performed using the UHPLC RS system (Dionex, Idstein, Germany) with DAD detection. Powdered plant material which corresponded to aboveground parts of plants collected from the field in four phenological phases $(100 \mathrm{mg}$ ) was extracted for $15 \mathrm{~min}$ with $50 \%$ methanol $(1.5 \mathrm{~mL})$ using an ultrasonic water bath at room temperature. Extracts were centrifuged (6 min; $2000 \mathrm{rpm})$ and supernatants were added to the conical flasks $(10 \mathrm{~mL})$. Extraction was repeated twice, then 50\% methanol was added to each flask. Samples $(2 \mathrm{~mL})$ were filtered using a syringe filter $(0.45 \mu \mathrm{m}, \mathrm{PVDF})$ and were analyzed using the HPLC method. Column, mobile phase, flow rate, gradient as well as column temperature were the same as described above. UV spectra (260 nm-oenothein B; $325 \mathrm{~nm}$ - chlorogenic acid; $350 \mathrm{~nm}$-quercetin 3-O-glucuronide) were recorded.

\section{Statistical analysis}

Data collected from the in vitro experiment were statistically analyzed using one-way analysis of variance (ANOVA) and the statistical significance was determined by applying Duncan's test with $\mathrm{p}$ value of 0.05 (Fig. 2). Phytochemical measurements were repeated four times for each tested sample and compound. These data were analyzed using ANOVA and the statistical significance was determined by applying Tukey's test with $\mathrm{p}$ value of 0.05 (Fig. 3, Tables 3-7). Dunett's test ( $\mathrm{p}$ value of 0.05 ) was applied to compare the content of individual metabolites in four phenological phases calculated as mean for all genotypes tested, and the average amount of bioactive compounds in the full blooming
Fig. 2 Mean shoot number per explant (multi-shoot) calculated for genotypes. Error bars express SD. Data followed by different letters are significantly different at $\mathrm{p} \leq 0.05$ according to Duncan's test (one-way ANOVA)
Shoot number

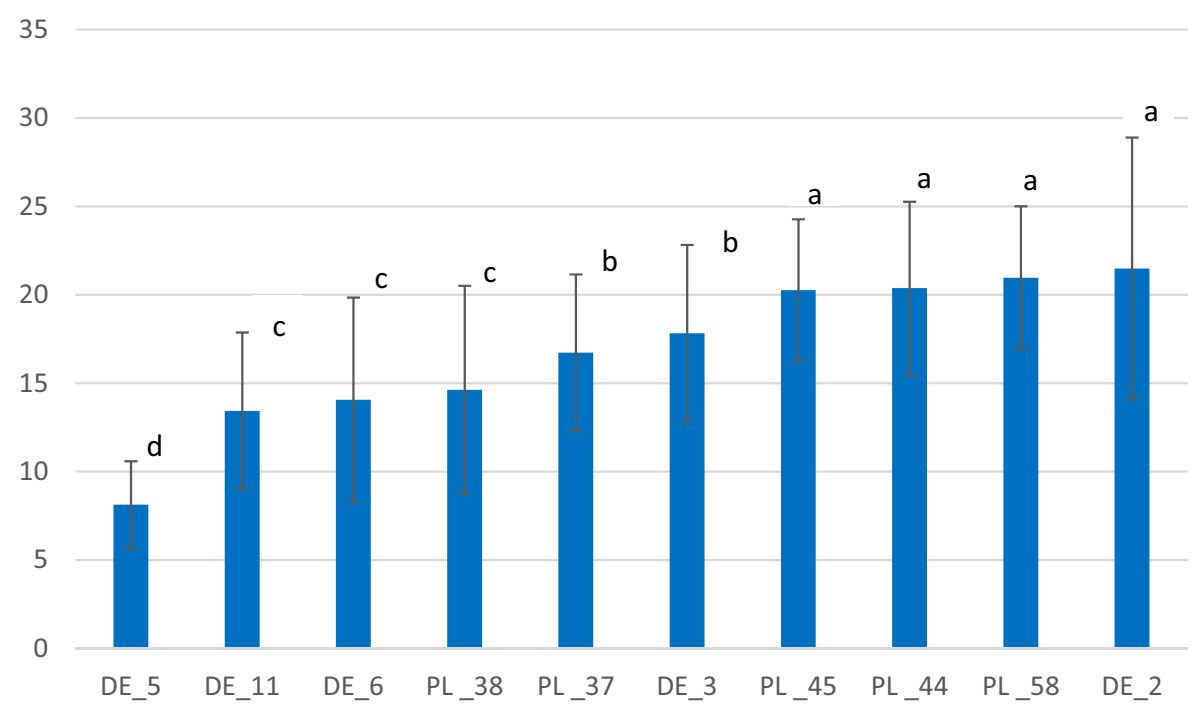


Fig. 3 Content of oenothein B ( $\left.\mathrm{mg} \mathrm{g}^{-1} \mathrm{DW}\right)$ in Ch. angustifolium shoots cultivated in vitro. Values are means of four repetitions for chemical analysis. Error bars express SD. Data followed by different letters are significantly different at $\mathrm{p} \leq 0.05$ according to Tukey's test

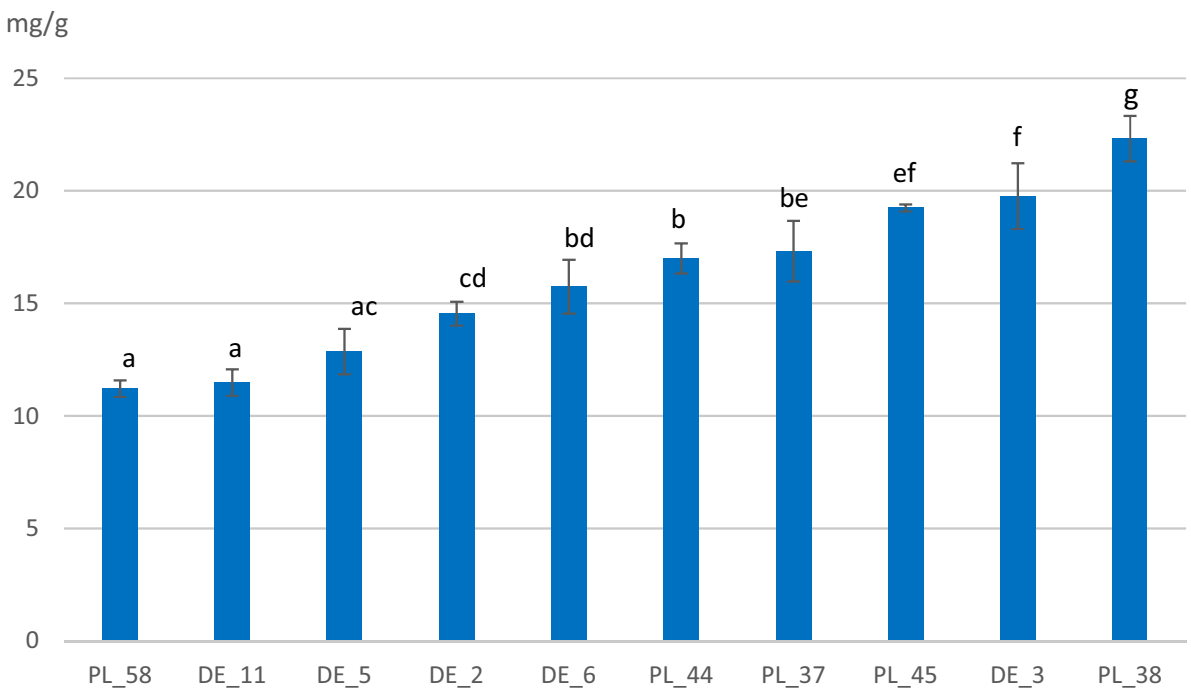

phase was set as a control (Table 8). All the statistical analyses were performed using STATISTICA 12 (StatSoft Inc., 2013).

\section{Results}

\section{Micropropagation and acclimatization}

In vitro cultures of $C h$. angustifolium were initiated from root explants and clonally propagated via multi-shoots (Fig. 1a). The efficiency of shoot multiplication varied between genotypes (lines) and ranged from 8.12 to 21.48 shoots per explant (Fig. 2). The highest numbers per shoots (21.5-20.3) were recorded for DE_2, PL_58, PL_44 and PL_45 lines. In turn, the lowest number of shoots per explants (8.1) was noted for genotype DE_5. The rest of the lines showed moderate efficiency of shoot organogenesis, with values between 17.8 and 13.4 shoots per explant. Isolated shoots rooted easily within 4 weeks and a high rooting rate was recorded, i.e. $98.5 \%$ (Fig. 1b). Plantlets after transplanting into the soil grew vigorously and $95.5 \%$ of them successfully survived the hardening process. The percentage of plants that survived in the field cultivation ranged from 80 to $92 \%$.

\section{Phytochemical characteristics of plants from in vitro cultures}

Fourteen constituents were identified in the in vitro cultured plants using the HPLC-DAD-MS/MS method (Table 1). Identified polyphenols can be divided into three
Table 1 Retention time, UV and MS/MS data of the compounds present in Ch. angustifolium plants (shoots) cultivated in vitro

\begin{tabular}{|c|c|c|c|c|c|}
\hline No & Compound & $\operatorname{Rt}(\min )$ & UV (nm) & $\begin{array}{l}{[\mathrm{M}-\mathrm{H}]} \\
\mathrm{MS}^{1}\end{array}$ & $\begin{array}{l}\text { Product ions' main peaks } \\
\mathrm{MS}^{2}\end{array}$ \\
\hline 1 & Unknown & 2.6 & 257 & 611 & - \\
\hline 2 & Galloyl glucose & 2.8 & 278 & 331 & 169,271 \\
\hline 3 & Digalloyl glucose & 4.1 & 272 & 483 & 331 \\
\hline 4 & Caffeic acid pentoside (I) & 9.4 & 265 & 311 & 149,179 \\
\hline 5 & 3-O-caffeoylquinic acid & 10.2 & 325 & 353 & 191,179 \\
\hline 6 & Caffeic acid pentoside (II) & 11.1 & 327 & 311 & 179 \\
\hline 7 & Oenothein $\mathrm{B}^{\mathrm{a}}$ & 16.5 & 263 & $1567 / 783^{*}$ & \\
\hline 8 & 5-O-caffeoylquinic acid & 17.1 & 323 & 353 & 191 \\
\hline 9 & Digalloyl-HHDP-glucose (I) & 17.6 & 273 & 785 & $633,483,300$ \\
\hline 10 & Ferulic acid pentoside & 19.6 & 326 & 325 & 193 \\
\hline 11 & Bis-HHDP-glucose & 21.5 & 260 & 783 & 765 \\
\hline 12 & Digalloyl-HHDP-glucose (III) & 23.5 & 272 & 785 & $633,483,301$ \\
\hline 13 & Unknown ellagitannin & 24.3 & 265 & - & - \\
\hline 14 & Quercetin 3-O-glucuronide $^{\mathrm{a}}$ & 37.7 & 260,355 & 477 & 301 \\
\hline
\end{tabular}

${ }^{*}[\mathrm{M}-2 \mathrm{H}]^{2-},{ }^{\mathrm{a}}$ Comparison with standards 
main groups: hydrolysable tannins, flavone derivatives, and phenolic acids. Absence of flavonoids (except of quercetin 3-O-glucuronide, 14) as well as relatively high levels of oenothein B (compound 7) and caffeic acid pentoside (6) were the most characteristic for in vitro material (Table 1). It is worth noting that identification of oenothein B was complemented by applying an external standard. 3-O-caffeoylquinic acid (5), ferulic acid pentoside (10) and hydrolysable tannins (compounds 2, 3 and 11) were detected in all in vitro samples. Among hydrolysable tannins, monomeric (e.g., bis-HHDP-glucose, 11) and dimeric (oenothein B, 7) ones were identified. The HPLC chromatograms of identified compounds are presented in Fig. 4a (Supplementary Information). Oenothein B was determined as a dominant compound. Content of this substance ranged from 11.21 to $22.32 \mathrm{mg} \mathrm{g}^{-1}$ dry weight (DW) depending on genotype (Fig. 3). The differences between samples were statistically significant, and the highest level of oenothein B (22.32 $\mathrm{mg} \mathrm{g}^{-1} \mathrm{DW}$ ) was recorded for line PL_38.

\section{Phytochemical characteristics of plants cultivated in field}

Comparing to the in vitro cultures, fireweed harvested from the field had a wider spectrum of constituents, particularly phenolic acids and flavonoids. In the above-ground parts of these plants 31 phytochemicals were determined (Table 2). Oenothein B (9) and quercetin 3-O-glucuronide (26) were the dominant compounds (Fig. 4b-c, Supplementary Information). Twenty-two compounds including hydrolysable tannins (compounds 4-9 and 14-19), phenolic acids (1, $3,7,10,24)$, and flavone derivatives $(21,22,25-30)$ were
Table 2 Retention time, UV and MS/MS data of the compounds present in Ch. angustifolium plants (aerial parts) grown in field

\begin{tabular}{|c|c|c|c|c|c|}
\hline No & Compound & $\mathrm{Rt}(\min )$ & $\mathrm{UV}(\mathrm{nm})$ & $\begin{array}{l}{[\mathrm{M}-\mathrm{H}]} \\
\mathrm{MS}^{1}\end{array}$ & $\begin{array}{l}\text { Product ions' main peaks } \\
\mathrm{MS}^{2}\end{array}$ \\
\hline 1 & Quinic acid & 2.6 & 280 & 191 & 111 \\
\hline 2 & Galloyl glucose & 2.8 & 278 & 331 & 169,271 \\
\hline 3 & Gallic acid & 3.9 & 270 & 169 & \\
\hline 4 & Galloyl-HHDP-glucose (I) & 4.0 & 270 & 633 & 301,481 \\
\hline 5 & Digalloyl glucose & 4.1 & 272 & 483 & 331 \\
\hline 6 & Galloyl-HHDP-glucose (III) & 5.6 & 265 & 633 & 301,481 \\
\hline 7 & 3-O-caffeoylquinic acid & 10.2 & 325 & 353 & 191,179 \\
\hline 8 & Unknown ellagitannin & 13.9 & 260 & - & - \\
\hline 9 & Oenothein $\mathrm{B}^{\mathrm{a}}$ & 16.4 & 263 & $1567 / 783^{*}$ & - \\
\hline 10 & 5-O-caffeoylquinic acid & 17.1 & 323 & 353 & 191 \\
\hline 11 & Digalloyl-HHDP-glucose (II) & 17.6 & 273 & 785 & $633,483,301$ \\
\hline 12 & 3-O-feruloylquinic acid & 17.9 & 315 & 367 & 193,134 \\
\hline 13 & 4- $O$-caffeoylquinic acid & 18.5 & 325 & 353 & 179,173 \\
\hline 14 & Unknown ellagitannin & 19.7 & 265 & - & - \\
\hline 15 & Unknown ellagitannin & 20.0 & 262 & - & - \\
\hline 16 & Bis-HHDP-glucose & 21.5 & 260 & 783 & 765 \\
\hline 17 & Digalloyl-HHDP-glucose (III) & 23.5 & 272 & 785 & $633,483,301$ \\
\hline 18 & Trimeric ellagitannin & 24.5 & 265 & $1175^{*}$ & 765,301 \\
\hline 19 & Trimeric ellagitannin & 25.0 & 262 & $1175^{*}$ & 765,301 \\
\hline 20 & Myricetin hexuronide & 31.0 & 358,260 & 479 & 317 \\
\hline 21 & Myricetin glucuronide & 31.6 & 357,262 & 493 & 317 \\
\hline 22 & Quercetin $O$-galloyl-hexoside & 33.9 & 263,354 & 615 & 463,301 \\
\hline 23 & Quercetin $O$-galloyl-hexoside & 35.3 & 263,355 & 615 & 463,301 \\
\hline 24 & Ellagic acid & 36.4 & 253,365 & 301 & 257,229 \\
\hline 25 & Quercetin $O$-hexoside & 37.0 & 260,355 & 463 & 301 \\
\hline 26 & Quercetin 3-O-glucuronide $^{\mathrm{a}}$ & 37.7 & 260,355 & 477 & 301 \\
\hline 27 & Quercetin $O$-pentoside & 41.1 & 260,353 & 433 & 301 \\
\hline 28 & Quercetin $O$-rhamnoside & 43.5 & 262,350 & 447 & 301 \\
\hline 29 & Kaempferol $O$-hexuronide & 43.4 & 265,345 & 461 & 285 \\
\hline 30 & Kaempferol $O$-rhamnoside & 49.8 & 265,340 & 431 & 285 \\
\hline 31 & Quercetin $O$-p-coumaroyl-hexoside & 56.6 & 265,315 & 609 & 463,301 \\
\hline
\end{tabular}

${ }^{*}[\mathrm{M}-2 \mathrm{H}]^{2-}$, ${ }^{\mathrm{C}}$ Comparison with standards 
detected in all samples. Among hydrolysable tannins, monomeric (e.g., bis-HHDP-glucose, 16), dimeric (oenothein $\mathrm{B}, 9)$ and trimeric (unknown trimeric ellagitannins, 18, 19) were identified.

\section{Content of oenothein B, 3-O-caffeoylquinic acid and flavonoids in four phenological phases of plants}

\section{Oenothein B}

Significant variation in content of oenothein B was noted regarding the phenological phases with respect to tested genotypes (Table 3). The highest content of oenothein B (86.51 $\left.\mathrm{mg} \mathrm{g}^{-1} \mathrm{DW}\right)$ was recorded for the PL_44 line. It was $20 \%$ higher than mean values for all genotypes in this phase. The result was statistically significant and clearly indicated the distinction between the rest of the accessions in this phase. Most of genotypes reached the highest yield of oenothein B during the vegetative phase. Only PL_45 and PL_37 genotypes showed different patterns of oenothein B accumulation. It should be noted that coefficient of variation (CV) values calculated for DE_6, PL_37 and PL_45 lines were the lowest $(7.35 \%, 7.49 \%$ and $8.16 \%$ relatively), which means that the changes in the oenothein B content were relatively small during the season compared to other genotypes.

\section{3-0-caffeoylquinic acid (chlorogenic acid)}

Among tested genotypes, the mean content of 3- $O$-caffeoylquinic acid (chlorogenic acid) ranged from 2.14 (DE_2) to $3.51 \mathrm{mg} \mathrm{g}^{-1}$

Table 3 Variation in oenothein B content $\left[\mathrm{mg} \mathrm{g}^{-1} \mathrm{DW}\right]$ between $C$. angustifolium genotypes in four phenological phases

\begin{tabular}{|c|c|c|c|c|c|c|}
\hline Genotype & Vegetative phase & Beginning of blooming & Full blooming & Green fruit phase & All phases & $\mathrm{CV}(\%)$ \\
\hline DE_2 & $57.06 \pm 1.79^{\mathrm{cd}}$ & $48.37 \pm 3.17^{\mathrm{a}}$ & $38.14 \pm 2.26^{\mathrm{e}}$ & $50.50 \pm 2.72^{\mathrm{ae}}$ & $48.52 \pm 7.37^{c}$ & 15.20 \\
\hline DE_3 & $70.14 \pm 2.04^{\mathrm{ab}}$ & $67.37 \pm 3.55^{\mathrm{cd}}$ & $69.96 \pm 2.02^{\mathrm{d}}$ & $45.36 \pm 2.16^{\mathrm{e}}$ & $63.21 \pm 10.93^{\mathrm{ab}}$ & 17.30 \\
\hline DE_5 & $74.16 \pm 3.38^{\mathrm{bf}}$ & $74.33 \pm 1.22^{\mathrm{df}}$ & $66.81 \pm 4.97^{\mathrm{cd}}$ & $58.17 \pm 3.27^{\mathrm{a}-\mathrm{d}}$ & $68.37 \pm 7.51^{\mathrm{a}}$ & 10.99 \\
\hline DE_6 & $61.67 \pm 1.35^{\mathrm{de}}$ & $53.70 \pm 2.07^{\mathrm{ab}}$ & $56.48 \pm 4.23^{\mathrm{ab}}$ & $53.61 \pm 2.21^{\mathrm{abc}}$ & $56.36 \pm 4.14^{\mathrm{bcd}}$ & 7.35 \\
\hline DE_11 & $66.61 \pm 3.01^{\mathrm{ae}}$ & $55.00 \pm 2.39^{\mathrm{ab}}$ & $51.76 \pm 0.70^{\mathrm{a}}$ & $50.46 \pm 4.37^{\mathrm{ae}}$ & $55.96 \pm 7.08^{\mathrm{bcd}}$ & 12.66 \\
\hline PL_37 & $54.56 \pm 2.89^{c}$ & $48.95 \pm 3.38^{\mathrm{a}}$ & $53.23 \pm 1.33^{\mathrm{a}}$ & $57.62 \pm 2.69^{\mathrm{a}-\mathrm{d}}$ & $53.59 \pm 4.01^{\mathrm{cd}}$ & 7.49 \\
\hline PL_38 & $78.61 \pm 3.74^{\mathrm{f}}$ & $56.49 \pm 2.42^{\text {be }}$ & $57.33 \pm 1.11^{\mathrm{ab}}$ & $59.27 \pm 3.72^{\mathrm{bcd}}$ & $62.92 \pm 9.77^{\mathrm{ab}}$ & 15.53 \\
\hline PL_44 & $86.51 \pm 1.68^{\mathrm{g}}$ & $67.89 \pm 3.30^{\mathrm{cd}}$ & $61.95 \pm 2.40^{\mathrm{bc}}$ & $61.11 \pm 3.51^{\mathrm{cd}}$ & $69.37 \pm 10.87^{\mathrm{a}}$ & 15.67 \\
\hline PL_45 & $71.05 \pm 2.37^{\mathrm{ab}}$ & $76.76 \pm 5.53^{f}$ & $67.61 \pm 3.55^{\mathrm{cd}}$ & $64.99 \pm 3.36^{\mathrm{d}}$ & $70.10 \pm 5.72^{\mathrm{a}}$ & 8.16 \\
\hline PL_58 & $71.35 \pm 3.16^{\mathrm{ab}}$ & $62.66 \pm 1.25^{\mathrm{ce}}$ & $61.76 \pm 3.17^{\mathrm{bc}}$ & $52.33 \pm 3.64^{\text {abe }}$ & $62.03 \pm 7.44^{\mathrm{abd}}$ & 11.99 \\
\hline All genotypes & $69.17 \pm 9.61$ & $61.15 \pm 10.13$ & $58.50 \pm 9.40$ & $55.34 \pm 6.34$ & $61.04 \pm 10.29$ & 12.23 \\
\hline CV (\%) & 13.89 & 16.57 & 16.07 & 11.46 & 16.85 & 30.08 \\
\hline
\end{tabular}

Values are mean \pm SD of four repetitions for chemical analysis. Mean values in column with the same letter are not significantly different at $\mathrm{p}=0.05$ (Tukey's multiple range test), CV - coefficient of variation

Table 4 Variation in 3-O-caffeoylquinic acid content $\left[\mathrm{mg} \mathrm{g}^{-1} \mathrm{DW}\right]$ between $C h$. angustifolium genotypes in four phenological phases

\begin{tabular}{|c|c|c|c|c|c|c|}
\hline Genotype & Vegetative phase & Beginning of blooming & Full blooming & Green fruit phase & All phases & $\mathrm{CV}(\%)$ \\
\hline DE_2 & $2.54 \pm 0.03^{f}$ & $2.63 \pm 0.11^{\mathrm{b}}$ & $2.16 \pm 0.15^{\mathrm{de}}$ & $1.23 \pm 0.07^{\mathrm{c}}$ & $2.14 \pm 0.58^{\mathrm{e}}$ & 27.06 \\
\hline DE_3 & $3.12 \pm 0.15^{\mathrm{ab}}$ & $2.70 \pm 0.10^{\mathrm{bc}}$ & $2.40 \pm 0.06^{\mathrm{ef}}$ & $1.94 \pm 0.06^{\mathrm{ad}}$ & $2.54 \pm 0.45^{\text {abe }}$ & 17.77 \\
\hline DE_5 & $3.30 \pm 0.09^{\mathrm{bc}}$ & $3.55 \pm 0.09^{\mathrm{ad}}$ & $2.77 \pm 0.23^{\mathrm{ab}}$ & $1.68 \pm 0.05^{\mathrm{ab}}$ & $2.83 \pm 0.75^{\mathrm{abc}}$ & 26.58 \\
\hline DE_6 & $2.84 \pm 0.07^{\mathrm{af}}$ & $3.00 \pm 0.13^{\text {ce }}$ & $2.56 \pm 0.09^{\mathrm{af}}$ & $1.79 \pm 0.05^{\mathrm{a}}$ & $2.55 \pm 0.49^{\text {abe }}$ & 19.21 \\
\hline DE_11 & $3.05 \pm 0.12^{\mathrm{ab}}$ & $2.74 \pm 0.15^{\mathrm{bc}}$ & $2.02 \pm 0.05^{\mathrm{d}}$ & $1.42 \pm 0.07^{\mathrm{bc}}$ & $2.31 \pm 0.66^{\mathrm{ae}}$ & 28.62 \\
\hline PL_37 & $3.17 \pm 0.17^{\mathrm{abc}}$ & $3.28 \pm 0.17^{\mathrm{de}}$ & $3.01 \pm 0.13^{\mathrm{bg}}$ & $2.17 \pm 0.21^{\mathrm{d}}$ & $2.91 \pm 0.48^{\mathrm{a}-\mathrm{d}}$ & 16.44 \\
\hline PL_38 & $3.84 \pm 0.24^{\mathrm{e}}$ & $3.38 \pm 0.22^{\mathrm{ad}}$ & $3.31 \pm 0.16^{\mathrm{cg}}$ & $2.58 \pm 0.22^{\mathrm{e}}$ & $3.28 \pm 0.51^{\mathrm{cd}}$ & 15.41 \\
\hline PL_44 & $3.80 \pm 0.15^{\mathrm{de}}$ & $3.69 \pm 0.09^{\mathrm{a}}$ & $3.37 \pm 0.16^{\mathrm{c}}$ & $3.18 \pm 0.17^{\mathrm{f}}$ & $3.51 \pm 0.29^{\mathrm{d}}$ & 8.21 \\
\hline PL_45 & $3.66 \pm 0.13^{\mathrm{de}}$ & $3.65 \pm 0.10^{\mathrm{a}}$ & $2.82 \pm 0.12^{\mathrm{ab}}$ & $2.62 \pm 0.11^{\mathrm{e}}$ & $3.19 \pm 0.50^{\mathrm{cd}}$ & 15.68 \\
\hline PL_58 & $3.47 \pm 0.17^{\mathrm{cd}}$ & $3.64 \pm 0.06^{\mathrm{a}}$ & $3.38 \pm 0.13^{\mathrm{c}}$ & $1.70 \pm 0.11^{\mathrm{ab}}$ & $3.05 \pm 0.82^{\mathrm{bcd}}$ & 26.74 \\
\hline All genotypes & $3.28 \pm 0.43$ & $3.23 \pm 0.42$ & $2.78 \pm 0.49$ & $2.03 \pm 0.59$ & $2.83 \pm 0.70$ & 20.17 \\
\hline $\mathrm{CV}(\%)$ & 12.98 & 13.13 & 17.55 & 29.13 & 24.60 & 33.44 \\
\hline
\end{tabular}

Values are mean \pm SD of four repetitions for chemical analysis. Mean values in column with the same letter are not significantly different at $\mathrm{p}=0.05$ (Tukey's multiple range test), CV - coefficient of variation 
DW (PL_44) (Table 4). The highest content $\left(3.84 \mathrm{mg} \mathrm{g}^{-1}\right.$ DW) was recorded for the PL_38 line in the vegetative phase. PL_44 genotype was characterized by a relatively high (from 3.18 to $\left.3.80 \mathrm{mg} \mathrm{g}^{-1} \mathrm{DW}\right)$ and stable $(\mathrm{CV}=8.21 \%)$ level of 3-O-caffeoylquinic acid during the whole season. The highest level of 3-O-caffeoylquinic acid was noted in the first two phases, i.e. in the vegetative and beginning of blooming ones, whereas a gradual decrease was observed from the full blooming phase to the green fruit phase.

\section{Flavonoids}

Fluctuation of flavonoids level was the highest among tested polyphenols and genotypes. The highest contents of quercetin 3-O-glucuronide $\left(21.44 \mathrm{mg} \mathrm{g}^{-1} \mathrm{DW}\right.$ and $20.29 \mathrm{mg} \mathrm{g}^{-1} \mathrm{DW}$ ) were recorded for PL_44 and DE_5 genotypes, respectively, at the beginning of the blooming phase (Table 5). Content of this flavonoid recorded for PL_44, PL_38 and PL_37 lines was relatively high and stable (CV $=6.48 \%, 7.84 \%$ and $7.95 \%$, respectively) during the season.

Mean content of the sum of kaempferol 3-O-glucuronide and quercetin 3-O-rhamnoside ranged from 2.05 (DE_2) to $4.39 \mathrm{mg} \mathrm{g}^{-1}$ DW (PL_38) (Table 6). The highest level of these flavonoids $\left(5.84 \pm 0.28 \mathrm{mg} \mathrm{g}^{-1} \mathrm{DW}\right)$ was recorded for PL_38 genotype in the full blooming phase. The result was statistically significant and clearly indicated the distinction between the rest of the lines in this

Table 5 Variation in quercetin 3-O-glucuronide content $\left[\mathrm{mg} \mathrm{g}^{-1} \mathrm{DW}\right]$ between $C h$. angustifolium genotypes in four phenological phases

\begin{tabular}{|c|c|c|c|c|c|c|}
\hline Genotype & Vegetative phase & Beginning of blooming & Full blooming & Green fruit phase & All phases & $\mathrm{CV}(\%)$ \\
\hline DE_2 & $10.43 \pm 0.31^{\mathrm{c}}$ & $11.83 \pm 0.90^{\mathrm{g}}$ & $8.95 \pm 0.54^{\mathrm{b}}$ & $8.97 \pm 0.97^{b}$ & $10.04 \pm 1.39^{\mathrm{e}}$ & 13.88 \\
\hline DE_3 & $17.41 \pm 0.64^{\mathrm{a}}$ & $9.84 \pm 0.66^{\mathrm{f}}$ & $9.70 \pm 0.56^{\mathrm{b}}$ & $18.19 \pm 0.56^{\mathrm{de}}$ & $13.78 \pm 4.19^{\mathrm{a}}$ & 30.43 \\
\hline DE_5 & $18.12 \pm 0.73^{\mathrm{a}}$ & $20.29 \pm 0.46^{\mathrm{de}}$ & $18.20 \pm 0.44^{\mathrm{ef}}$ & $12.90 \pm 0.86^{\mathrm{a}}$ & $17.38 \pm 2.88^{\mathrm{bcd}}$ & 16.55 \\
\hline DE_6 & $15.26 \pm 0.81^{\mathrm{b}}$ & $18.26 \pm 1.00^{\mathrm{bc}}$ & $15.05 \pm 0.86^{\mathrm{ad}}$ & $11.03 \pm 0.19^{\mathrm{ab}}$ & $14.90 \pm 2.74^{\mathrm{abc}}$ & 18.41 \\
\hline DE_11 & $18.20 \pm 0.72^{\mathrm{a}}$ & $16.09 \pm 0.76^{\mathrm{a}}$ & $13.18 \pm 0.10^{\mathrm{c}}$ & $10.22 \pm 0.72^{\mathrm{b}}$ & $14.42 \pm 3.16^{\mathrm{a}}$ & 21.94 \\
\hline PL_37 & $15.29 \pm 0.77^{\mathrm{b}}$ & $17.54 \pm 1.10^{\mathrm{abc}}$ & $16.26 \pm 0.56^{\mathrm{a}}$ & $15.62 \pm 1.48^{\mathrm{c}}$ & $16.18 \pm 1.29^{\mathrm{abc}}$ & 7.95 \\
\hline PL_38 & $18.74 \pm 1.07^{\mathrm{a}}$ & $16.53 \pm 1.10^{\mathrm{ab}}$ & $18.05 \pm 0.74^{\mathrm{e}}$ & $16.63 \pm 1.33^{\mathrm{cd}}$ & $17.49 \pm 1.37^{\mathrm{cd}}$ & 7.84 \\
\hline PL_44 & $19.04 \pm 0.66^{\mathrm{a}}$ & $21.44 \pm 0.98^{\mathrm{e}}$ & $19.71 \pm 1.02^{\mathrm{f}}$ & $19.37 \pm 1.13^{\mathrm{e}}$ & $19.89 \pm 1.29^{\mathrm{d}}$ & 6.48 \\
\hline PL_45 & $13.54 \pm 0.50^{\mathrm{b}}$ & $18.57 \pm 0.58^{\mathrm{cd}}$ & $14.22 \pm 0.58^{\mathrm{cd}}$ & $12.49 \pm 0.45^{\mathrm{a}}$ & $14.70 \pm 2.44^{\mathrm{ab}}$ & 16.57 \\
\hline PL_58 & $15.08 \pm 0.81^{\mathrm{b}}$ & $15.95 \pm 0.15^{\mathrm{a}}$ & $16.27 \pm 0.42^{\mathrm{a}}$ & $12.47 \pm 0.84^{\mathrm{a}}$ & $14.94 \pm 1.64^{\mathrm{abc}}$ & 10.99 \\
\hline All genotypes & $16.11 \pm 2.70$ & $16.63 \pm 3.49$ & $14.96 \pm 3.46$ & $13.79 \pm 3.45$ & $15.37 \pm 3.44$ & 15.10 \\
\hline CV (\%) & 16.74 & 20.99 & 23.12 & 25.04 & 22.38 & 49.03 \\
\hline
\end{tabular}

Values are mean \pm SD of four repetitions for chemical analysis. Mean values in column with the same letter are not significantly different at $\mathrm{p}=0.05$ (Tukey's multiple range test), CV - coefficient of variation

Table 6 Variation in content of sum of kaempferol 3-O-glucuronide and quercetin 3-O-rhamnoside [mg g ${ }^{-1}$ DW] between Ch. angustifolium genotypes in four phenological phases

\begin{tabular}{|c|c|c|c|c|c|c|}
\hline Genotype & Vegetative phase & Beginning of blooming & Full blooming & Green fruit phase & All phases & $\mathrm{CV}(\%)$ \\
\hline DE_2 & $1.10 \pm 0.04^{\mathrm{g}}$ & $2.15 \pm 0.14^{\mathrm{b}}$ & $2.08 \pm 0.16^{\mathrm{f}}$ & $2.85 \pm 0.22^{\mathrm{ab}}$ & $2.05 \pm 0.66^{\mathrm{a}}$ & 32.17 \\
\hline DE_3 & $1.79 \pm 0.07^{\mathrm{bc}}$ & $2.80 \pm 0.18^{\mathrm{a}}$ & $5.07 \pm 0.42^{\mathrm{e}}$ & $2.79 \pm 0.04^{\mathrm{ab}}$ & $3.11 \pm 1.26^{\mathrm{b}-\mathrm{e}}$ & 40.40 \\
\hline DE_5 & $1.51 \pm 0.06^{\mathrm{a}}$ & $1.74 \pm 0.05^{\mathrm{b}}$ & $3.08 \pm 0.17^{\mathrm{ab}}$ & $3.17 \pm 0.17^{\mathrm{a}}$ & $2.38 \pm 0.79^{\mathrm{ab}}$ & 33.20 \\
\hline DE_6 & $1.55 \pm 0.09^{\mathrm{ab}}$ & $1.98 \pm 0.12^{\mathrm{b}}$ & $3.35 \pm 0.09^{\mathrm{b}}$ & $3.24 \pm 0.11^{\mathrm{ac}}$ & $2.53 \pm 0.81^{\mathrm{abc}}$ & 32.12 \\
\hline DE_11 & $1.40 \pm 0.05^{\mathrm{a}}$ & $2.96 \pm 0.16^{\mathrm{a}}$ & $4.09 \pm 0.18^{\mathrm{c}}$ & $2.67 \pm 0.08^{\mathrm{b}}$ & $2.78 \pm 1.00^{\mathrm{a}-\mathrm{e}}$ & 35.80 \\
\hline PL_37 & $2.04 \pm 0.10^{\mathrm{cd}}$ & $2.80 \pm 0.22^{\mathrm{a}}$ & $2.72 \pm 0.07^{\mathrm{a}}$ & $3.20 \pm 0.28^{\mathrm{ac}}$ & $2.69 \pm 0.46^{\mathrm{a}-\mathrm{d}}$ & 17.13 \\
\hline PL_38 & $2.89 \pm 0.18^{\mathrm{ef}}$ & $4.35 \pm 0.29^{\mathrm{d}}$ & $5.84 \pm 0.28^{g}$ & $4.46 \pm 0.31^{\mathrm{f}}$ & $4.39 \pm 1.10^{\mathrm{f}}$ & 25.12 \\
\hline PL_44 & $2.96 \pm 0.12^{\mathrm{f}}$ & $4.09 \pm 0.28^{\mathrm{cd}}$ & $3.16 \pm 0.13^{\mathrm{ab}}$ & $3.73 \pm 0.24^{\mathrm{de}}$ & $3.49 \pm 0.50^{\mathrm{def}}$ & 14.40 \\
\hline PL_45 & $2.15 \pm 0.09^{\mathrm{d}}$ & $3.71 \pm 0.10^{\mathrm{c}}$ & $4.60 \pm 0.22^{\mathrm{de}}$ & $4.22 \pm 0.13^{\mathrm{ef}}$ & $3.67 \pm 0.97^{\mathrm{ef}}$ & 26.53 \\
\hline PL_58 & $2.67 \pm 0.15^{\mathrm{e}}$ & $3.18 \pm 0.05^{\mathrm{a}}$ & $4.16 \pm 0.09^{\mathrm{cd}}$ & $3.69 \pm 0.27^{\mathrm{cd}}$ & $3.42 \pm 0.59^{\text {cde }}$ & 17.33 \\
\hline All genotypes & $2.01 \pm 0.63$ & $2.98 \pm 0.86$ & $3.81 \pm 1.12$ & $3.40 \pm 0.61$ & $3.05 \pm 1.06$ & 27.42 \\
\hline CV (\%) & 31.64 & 28.86 & 29.29 & 17.92 & 34.87 & 32.17 \\
\hline
\end{tabular}

Values are mean \pm SD of four repetitions for chemical analysis. Mean values in column with the same letter (a...g) are not significantly different at $\mathrm{p}=0.05$ (Tukey's multiple range test), CV - coefficient of variation 
Table 7 Variation in kaempferol 3-O-rhamnoside content $\left[\mathrm{mg} \mathrm{g}^{-1} \mathrm{DW}\right]$ between $C$. angustifolium genotypes in four phenological phases

\begin{tabular}{|c|c|c|c|c|c|c|}
\hline Genotype & Vegetative phase & Beginning of blooming & Full blooming & Green fruit phase & All phases & $\mathrm{CV}(\%)$ \\
\hline DE_2 & $0.78 \pm 0.03^{\mathrm{e}}$ & $1.66 \pm 0.13^{\mathrm{ab}}$ & $1.84 \pm 0.13^{\mathrm{ab}}$ & $1.38 \pm 0.13^{\mathrm{ac}}$ & $1.42 \pm 0.43^{\mathrm{a}}$ & 30.35 \\
\hline DE_3 & $0.25 \pm 0.01^{\mathrm{d}}$ & $1.55 \pm 0.08^{\mathrm{a}}$ & $2.74 \pm 0.20^{\mathrm{cd}}$ & $1.15 \pm 0.03^{\mathrm{ab}}$ & $1.42 \pm 0.93^{\mathrm{a}}$ & 65.33 \\
\hline DE_5 & $0.57 \pm 0.02^{\mathrm{b}}$ & $0.94 \pm 0.07^{\mathrm{c}}$ & $2.09 \pm 0.11^{\mathrm{b}}$ & $1.79 \pm 0.16^{\mathrm{d}}$ & $1.35 \pm 0.64^{\mathrm{a}}$ & 47.59 \\
\hline DE_6 & $0.32 \pm 0.03^{\mathrm{d}}$ & $0.89 \pm 0.07^{\mathrm{c}}$ & $4.00 \pm 0.14^{\mathrm{e}}$ & $1.68 \pm 0.10^{\mathrm{cd}}$ & $1.72 \pm 1.45^{\mathrm{ab}}$ & 84.35 \\
\hline DE_11 & $0.68 \pm 0.03^{\mathrm{ac}}$ & $2.08 \pm 0.12^{\mathrm{d}}$ & $3.02 \pm 0.13^{\mathrm{c}}$ & $0.85 \pm 0.05^{\mathrm{b}}$ & $1.66 \pm 0.99^{\mathrm{ab}}$ & 59.78 \\
\hline PL_37 & $0.64 \pm 0.04^{\mathrm{ab}}$ & $1.62 \pm 0.09^{\mathrm{ab}}$ & $2.12 \pm 0.08^{b}$ & $2.15 \pm 0.15^{\mathrm{e}}$ & $1.63 \pm 0.64^{\mathrm{ab}}$ & 38.94 \\
\hline PL_38 & $0.73 \pm 0.04^{\text {ce }}$ & $1.41 \pm 0.06^{\mathrm{a}}$ & $1.66 \pm 0.07^{\mathrm{a}}$ & $1.19 \pm 0.06^{\mathrm{a}}$ & $1.25 \pm 0.36^{\mathrm{a}}$ & 28.73 \\
\hline PL_44 & $0.88 \pm 0.03^{\mathrm{f}}$ & $3.57 \pm 0.20^{\mathrm{e}}$ & $2.60 \pm 0.17^{\mathrm{c}}$ & $2.88 \pm 0.21^{\mathrm{f}}$ & $2.48 \pm 1.03^{\mathrm{b}}$ & 41.60 \\
\hline PL_45 & $0.67 \pm 0.03^{\mathrm{ac}}$ & $1.85 \pm 0.09^{\mathrm{bd}}$ & $1.69 \pm 0.06^{\mathrm{a}}$ & $1.36 \pm 0.04^{\mathrm{a}}$ & $1.39 \pm 0.47^{\mathrm{a}}$ & 33.87 \\
\hline PL_58 & $0.62 \pm 0.03^{\mathrm{ab}}$ & $1.50 \pm 0.04^{\mathrm{a}}$ & $2.46 \pm 0.04^{\mathrm{c}}$ & $2.22 \pm 0.16^{\mathrm{e}}$ & $1.70 \pm 0.74^{\mathrm{ab}}$ & 43.69 \\
\hline All genotypes & $0.61 \pm 0.19$ & $1.71 \pm 0.73$ & $2.42 \pm 0.70$ & $1.67 \pm 0.60$ & $1.60 \pm 0.87$ & 47.42 \\
\hline CV (\%) & 30.82 & 42.50 & 28.87 & 35.89 & 54.57 & 37.06 \\
\hline
\end{tabular}

Values are mean \pm SD of four repetitions for chemical analysis. Mean values in column with the same letter are not significantly different at $\mathrm{p}=0.05$ (Tukey's multiple range test), $\mathrm{CV}$ - coefficient of variation

phase. Most genotypes reached the highest peak in the full blooming phase.

Mean content of kaempferol 3- $O$-rhamnoside ranged from 1.25 (PL_38) to $2.48 \mathrm{mg} \mathrm{g}^{-1} \mathrm{DW}$ (PL_44) (Table 7). The highest content of kaempferol 3-O-rhamnoside $\left(4.00 \pm 0.14 \mathrm{mg} \mathrm{g}^{-1} \mathrm{DW}\right)$ was recorded for the DE_6 line in the full blooming phase, and this result reached statistical significance. Only two genotypes (PL_44 and PL_45) expressed a different pattern of kaempferol 3-O-rhamnoside accumulation. PL_44 and PL_45 plants achieved the highest level earlier, at the beginning of blooming. The large increase in the content of kaempferol 3-O-rhamnoside content (12-fold and 10-fold, respectively) during the season was noted for DE_6 and DE_3 genotypes.

\section{Phytochemical variability during vegetation}

To verify hypothesis that full blooming phase is the best harvest time, the content of the tested metabolites was compared in four phenological phases, and full blooming phase was set as a control (Table 8). Significantly higher levels of flavonoids: kaempferol 3-O-rhamnoside and sum of kaempferol 3-O-glucuronide and quercetin- 3-O-rhamnoside were noted in full blooming phase, whereas oenothein B and chlorogenic acid contents were lower. The mean content of quercetin 3-O-glucuronide did not show any variation in relation to developmental phase.

\section{Discussion}

Genotypes or chemotypes which are stable regarding the expression of secondary metabolites during the season are important for developing new forms or cultivars. Knowledge of metabolite fluctuation during physiological development allows the determination of optimum harvesting time and is essential for the success of each commercial agricultural undertaking. Therefore, studies on intraspecies variability in metabolite production and on the relationship with the phenological phases significantly contribute to a solid basis for genotype selection aimed at better food or higher quality of pharmaceuticals. In the present study, in vitro cultures were used for multiplication of plants providing homogenous and sufficient material from each accession for the study on genotypic and developmental variation in ex vitro conditions.
Table 8 Variation in content of oenothein B, 3-O-caffeoylquinic acid and flavonoids $\left[\mathrm{mg} \mathrm{g}^{-1}\right.$ DW] in four phenological phases

\begin{tabular}{llllll}
\hline Phase & OB & CA & QG & KG+QR & KR \\
\hline Control & $58.50 \pm 9.40^{\mathrm{a}}$ & $2.78 \pm 0.49^{\mathrm{a}}$ & $14.96 \pm 3.46^{\mathrm{a}}$ & $3.81 \pm 1.12^{\mathrm{a}}$ & $2.42 \pm 0.70^{\mathrm{a}}$ \\
Vegetative phase & $69.17 \pm 9.61^{\mathrm{b}}$ & $3.28 \pm 0.43^{\mathrm{b}}$ & $16.11 \pm 2.70^{\mathrm{a}}$ & $2.01 \pm 0.63^{\mathrm{b}}$ & $0.61 \pm 0.19^{\mathrm{b}}$ \\
Beginning of blooming & $61.15 \pm 10.13^{\mathrm{a}}$ & $3.23 \pm 0.42^{\mathrm{b}}$ & $16.63 \pm 3.49^{\mathrm{a}}$ & $2.98 \pm 0.86^{\mathrm{b}}$ & $1.71 \pm 0.73^{\mathrm{b}}$ \\
Green fruit phase & $55.34 \pm 6.34^{\mathrm{a}}$ & $2.03 \pm 0.59^{\mathrm{c}}$ & $13.79 \pm 3.45^{\mathrm{a}}$ & $3.40 \pm 0.61^{\mathrm{a}}$ & $1.67 \pm 0.60^{\mathrm{b}}$ \\
\hline
\end{tabular}

Content of metabolites in full blooming phase was set as a control. $O B$ oenothein B, $C A$ 3- $O$-caffeoylquinic acid, $Q G$ quercetin 3-O-glucuronide, $K G+Q R$ sum of kaempferol 3-O-glucuronide and quercetin 3- $O$-rhamnoside, $K R$ kaempferol 3- $O$-rhamnoside. Mean values (calculated for all genotypes) in column with the same letter are not significantly different at $p=0.05$ (Dunett's post hoc test) 
In our research, ten genotypes (lines) were subjected to micropropagation and phytochemical studies. Tested genotypes significantly differed in a number of proliferated shoots per explants (Fig. 2). A high reproduction rate ( $>20$ shoots per explant) was recorded for four lines (PL_45, PL_44, PL_58, DE_2). The micropropagation efficiency depends on culture conditions, selection of plant growth regulators (PGRs), micropropagation technique, type of explant, age of donors' plants and genotype. Organogenesis from root explants (Turker et al. 2008; Dreger et al. 2016) and nodal explants of fireweed (Dreger et al. 2020) was reported previously. A higher regeneration rate ( $>30$ shoots per explants) was noted for root explants (Turker et al. 2008; Dreger et al. 2016), but without respect to the genotype effect. Type of explant and PGRs play a key role in the regeneration process, but its efficiency depends on genotype (Zimik and Arumugam 2017; Pandey et al. 2020). Genotypes differ in their levels of endogenous phytohormones. In vitro shoot regeneration is controlled by the exogenous cytokinin and auxin balances, therefore the different levels of endogenous phytohormones is assumed to be the main cause of variation between genotypes with different degrees of competence (Kumari et al. 2018). The high regeneration rate as well as high survival rate of acclimatized plants $(95.5 \%)$ confirmed the appropriate selection of the PGRs as well as cultivation and micropropagation technique. Genotypes characterized by high regeneration rate should be considered as good candidates for large scale multiplication and production of the plantlets.

Phytochemical screening of in vitro regenerated shoots of Ch. angustifolium revealed the presence of 14 compounds in contrast to 31 constituents identified in samples collected from the field (Tables 1 and 2). First of all, absence of flavonoids (except of quercetin 3-O-glucuronide) was characteristic for in vitro material (Table 1). Generally, plants cultivated in vitro synthesize fewer compounds than those grown in the field due to completely different environmental conditions (Cardoso et al. 2019). Moreover, in vitro growing plants are kept in the juvenile stage and do not go through the full development phases, so specific to tissue and organ compounds are absent or minor. Presence of some flavonoids such as quercetin 3-O-rhamnoside, myricetin 3-O-rhamnoside and kaempferol- 3-O-rhamnoside is closely related to flowers and their development (Baert et al. 2017). Tissue-specific regulation of flavonoid biosynthesis has been intensively studied and confirmed in others species (He et al. 2020; Yuan et al. 2020). Therefore, the absence of some flavonoids in in vitro cultured shoots can be explained by specific tissue and developmental regulation of flavonoid biosynthesis. Although in vitro plants contained less phenolic compounds than those cultivated in field, but two bioactive compounds: oenothein $\mathrm{B}$ and caffeic acid pentoside were abundant in shoot cultures (Table 1). Comparable oenothein B content $\left(24.6 \mathrm{mg} \mathrm{g}^{-1} \mathrm{DW}\right)$ in Ch. angustifolium shoot cultures was determined previously (Dreger et al. 2020). Presence of caffeic acid pentoside is reported for the first time in in vitro cultures of fireweed, although this compound and other caffeic acid derivatives are commonly found in medicinal plants with strong antioxidant action (Tajner-Czopek et al. 2020).

Contrary to in vitro cultures, plants harvested from the field contained the full spectrum of polyphenols, including flavonoids: quercetin 3-O-glucuronide, kaempferol 3-O-rhamnoside, kaempferol 3-O-glucuronide and quercetin 3-O-rhamnoside. Oenothein B (38.1-86.5 $\left.\mathrm{mg} \mathrm{g}^{-1} \mathrm{DW}\right)$ and quercetin 3-O-glucuronide (8.95-21.44 $\left.\mathrm{mg} \mathrm{g}^{-1} \mathrm{DW}\right)$ were the most abundant compounds. Total flavonoid content varied among accessions from 13.51 to $25.86 \mathrm{mg} \mathrm{g}^{-1}$ DW. This is consistent with other reports (Hevesi Tóth et al. 2009; Kiss et al. 2011; Stolarczyk et al. 2013). Oenothein $\mathrm{B}$ is the predominant polyphenol in this species (Granica et al. 2012; Beart 2017), while total flavonoid content is about 2\% (Ducrey et al. 1997; Kiss et al. 2011; Kaškoniene et al. 2015).

The important part of our study was analysis of genotypic variability in polyphenols accumulation. Quantitative analysis of oenothein B with respect to genotypes showed relatively high variation of its content under in vitro conditions confirming that biosynthesis of this compound is under control of genetic factors. It should be stressed that all accessions were kept on the same medium and treated in the same way. Oenothein B content as well as its variation among genotypes did not simply extrapolate to field conditions (Fig. 3, Table 3). Generally, content of this ellagitannin was three-fold to five-fold higher in ex vitro conditions, but did not reflect the variation among genotypes observed in in vitro cultures. Low oenothein B-producing genotypes (PL_58, DE_11, DE_5) exhibited nearly five-fold increased content of this metabolite when they were transferred to the field. On the other hand, PL_38 plants, distinguished by the highest oenothein B level (22.32 $\left.\mathrm{mg} \mathrm{g}^{-1} \mathrm{DW}\right)$ under in vitro conditions, showed only a 2.8-fold increase of oenothein $\mathrm{B}$ content when grown in the field. Genotypic variation in oenothein B level under ex vitro conditions was strongly affected by environmental factors. The highest content of oenothein B $\left(86.51 \mathrm{mg} \mathrm{g}^{-1} \mathrm{DW}\right)$ was recorded for PL_44 genotype in vegetative phase and it was $20 \%$ higher than mean values for all genotypes in this phase. Differences among genotypes in other phenological phases were not so distinct or statistically significant. This is with line with Baert et al. (2017), who found relatively small inter-individual and moderate inter-population variation in oenothein B concentration. In the mentioned study, plant material was harvested at blooming phase therefore the differences were small or moderate. 
In the present study, most genotypes showed a similar pattern of oenothein B accumulation, and the highest values of this compound were recorded in the vegetative phase, whereas the lowest concentration was observed in the green fruit phase. This is consistent with the observations of Jürgenson et al. (2012), who recorded the highest tannin content in young plants in May, whereas in older ones it declined. Enhanced production of ellagitannins might be a part of the defense strategy against herbivores aimed at protecting young plants in order to increase reproductive success. The defensive role of ellagitannins in plants against herbivores and pathogens is well documented (Mamaní et al. 2012; Moilanen et al. 2016; Martos et al. 2020). Also oenothein B showed significant anti-herbivore (Anstett et al. 2019) and antimicrobial properties (Hatano et al. 2005).

Fluctuations of 3-O-caffeoylquinic acid level between genotypes of fireweed were relatively small or moderate (Table 4). Among accessions tested, PL_44 plants accumulated high and stable $(\mathrm{CV}=8.21 \%)$ content of this substance during vegetation in contrast to the other genotypes. In our study, the highest content of this phenolic acid was recorded in the vegetative and beginning of blooming phases, then the level was gradually declined (Tables 4 and 8). A similar pattern of 3- $O$-caffeoylquinic acid accumulation during the season in Polish climatic conditions was observed for Sorbus domestica leaves (Rutkowska et al. 2020). The highest content of this compound was recorded in May (1.68 $\mathrm{mg} \mathrm{g}^{-1} \mathrm{DW}$ ), whereas the lowest was recorded in October (0.36 $\left.\mathrm{mg} \mathrm{g}^{-1} \mathrm{DW}\right)$. Gradually declining level of phenolic acids might be explain by their protective role against UV radiation during foliar development. Biosynthesis of phenolic acids reflects an early response to UV radiation among other stressors (Petrulová et al. 2014). Phenolic acids act as UV filters and potent radical scavengers, which attenuate harmful UV radiation during foliar development (Mondolot et al. 2006; Li et al. 2019), whereas in the full blooming phase this role is shared by many others polyphenols i.a. flavonoids.

Genotypic variability in the content of flavonoids was the greatest among tested polyphenols (Tables 5-7). Variation in individual flavonoid level was heterogeneous and ranged from moderate (quercetin 3-O-glucuronide $\mathrm{CV}=22.38 \%$ ) to high (kaempferol 3-O-rhamnoside, $\mathrm{CV}=54.57 \%$ ). Genotype of PL_44 was relatively abundant in both flavonoids quercetin 3-O-glucuronide and kaempferol 3- $\mathrm{O}$-rhamnoside, whereas PL_38 plants were the most rich in kaempferol 3-O-glucuronide and quercetin 3-O-rhamnoside. Quercetin 3-O-glucuronide (miqualianin) was the most abundant flavonoid, which was consistent with previous reports (Stolarczyk et al. 2013; Granica et al. 2014). The maximal mean value recorded for miquelianin was $19.89 \mathrm{mg} \mathrm{g}^{-1} \mathrm{DW}$ (PL_44), which was nearly two-fold higher than the lowest recorded value of $10.04 \mathrm{mg} \mathrm{g}^{-1} \mathrm{DW}$ (DE_2). It is worth noting that it was two-fold higher and 3.5-fold higher than reported by Monschein et al. (2015) and Baert et al. (2017), respectively. The PL_44 genotype accumulated the highest miquelianin content, and its level was very stable during the season $(\mathrm{CV}=6.48 \%)$, which makes it a good candidate for early selection. Seasonal variation for this compound was moderate, without a clearly distinguished peak (Table 8). Miquelianin is definitely accumulated in leaves (Monschein et al. 2015; Baert et al. 2017), which are the target organs for this flavonoid, which could explain the lack of peak during blooming. In contrast to miquelianin, quercetin 3-O-rhamnoside (quercitrin) and kaempferol 3- $O$-rhamnoside (afzelin) are almost exclusively accumulated in flowers (Baert et al. 2017), whereas kaempferol 3-O-glucuronide accumulates in both types of organ equally (Monschein et al. 2015; Baert et al. 2017). Fluctuation of afzelin level during vegetation was the highest among flavonoids tested (Tables 7 and 8). The highest content of this substance was recorded in full blooming phase (2.42 $\mathrm{mg} \mathrm{g}^{-1} \mathrm{DW}$, on average). Similarly, the highest amount of sum of kaempferol 3-O-glucuronide and quercetin 3-O-rhamnoside was detected in the full blooming phase (Tables 6 and 8). This trend in seasonal variation of these flavonoids was also reported by Maruška et al. (2014), who concluded that the most valuable plant raw material of fireweed was collected during the massive blooming phase. To verify this hypothesis, the mean content of tested metabolites was compared in four developmental phases and full blooming phase was set as the control (Table 8). The results confirmed this hypothesis-that raw material contained the richest polyphenols composition in full blooming phase, but the maximal concentrations of oenothein $\mathrm{B}$ and chlorogenic acid were recorded in vegetative phase.

Breeding programs are based on the recommendations for standardization of the plant raw material and take into account its potential industrial use. Oenothein B and quercetin 3-O-glucuronide have been proposed as the marker compounds for the identification and standardization of fireweed raw material (Bazylko et al. 2007; Kiss et al. 2011; Monschein et al. 2015). Among Ch. angustifolium accessions, genotype of PL_44 was characterized by high and stable content of oenothein $\mathrm{B}$ and quercetin 3-O-glucuronide as well as a relatively high level of other flavonoids, therefore, it is a good candidate for further breeding process. Oenothein B is a main bioactive compound with therapeutic potential in BPH due to complex mechanism of action involving the regulation of androgen levels, inhibition of prostate-specific antigen (PSA) as well as anti-proliferative and apoptotic properties (Hiermann et al. 1998; Vitalone et al. 2001; Stolarczyk et al. 2013). The results of clinical trial (Esposito et al. 2021) and numerous preclinical studies indicated that $C h$. angustifolium extracts can be used as drugs or food supplements. Accumulating evidence suggests 
that regular consumption of ellagitannin-rich products can help reduce the risk of some chronic diseases, and may be useful in cancer prevention (Garcia-Muñoz \& Vaillant 2014). Ellagitannins are classified as nutraceuticals due to an array of biological activities, including antioxidant, antiinflammatory, anticancer, antidiabetic, antiaging, and antimicrobial. Currently, attention has also been paid to their metabolites-urolithins, which are produced by the intestinal microbiota (García-Villalba et al. 2020). There is a great interest in the application of urolithins as active forms of ellagitannins in the prevention of inflammatory bowel diseases, cardiovascular, metabolic syndrome, as well as neurodegenerative diseases. Flavonoids also have great therapeutic potential as they exhibit strong anti-inflammatory activity (Hiermann et al. 1998; Baral et al. 2017). Ch. angustifolium extract can be used in cosmetics manufacture. Skin photoprotection and anti-aging effect of fireweed extract were demonstrated in in vitro and in vivo tests (Ruszová et al. 2013). It should be notice that the beneficial properties of fireweed are attributed to the synergic effect of polyphenols like ellagitannins, flavonoids and phenolic acids. Therefore, future breeding programs should be focused on plants characterized by the richest composition of polyphenols.

\section{Conclusion}

The micropropagation study of $C h$. angustifolium showed relatively high variation in shoot proliferation of this species depending on the genotype. Hence, the evaluation of the multiplication efficiency was necessary to select accessions suitable for mass production of a high quality plant material. In our research, several lines (DE_2, PL_58, PL_44, PL_45) were characterized by a high reproductive rate ( $>20$ shoots per explants), which makes them good candidates for early selection.

The results of the phytochemical analyses exhibited that in vitro grown plants of $C h$. angustifolium are relatively good source of some bioactive compounds, mainly oenothein B and caffeic acid pentoside. This finding may inspire new research on the ellagitannins production in in vitro cultures. On the other hand, our study confirmed that fireweed plants harvested from the field cultivations contain the full spectrum of polyphenols characteristic for this species, and oenothein $\mathrm{B}$ and quercetin 3-O-glucuronide are the most abundant. The results of analysis of variance indicated slight or moderate differences between tested genotypes, but some of them accumulated a higher and more stable level of bioactive compounds during the growing season.

In our study, the maximal content of oenothein B was recorded in the vegetative phase of fireweed, while some flavonoids (sum of kaempferol 3-O-glucuronide and quercetin 3-O-rhamnoside, kaempferol 3-O-rhamnoside) were found in the highest amount in full blooming phase, which imply different optimal harvest time. Generally, harvest time should be adjusted to the content of active compounds and to the intended use of the raw material. In the full blooming phase of fireweed, the highest concentration of some flavonoids and still a relatively great level of oenothein B were determined. Regarding that the beneficial properties of fireweed are attributed to the synergic effect of polyphenols, therefore full blooming phase is the optimal harvest time.

Ch. angustifolium genotype of PL_44 was characterized by high content of oenothein $\mathrm{B}$ and quercetin 3-O-glucuronide as well as a relatively high level of other flavonoids. Based on the results of phytochemical and micropropagation studies, we can conclude that PL_44 genotype is the best candidate for early selection and further breeding programs aimed at obtaining a suitable industrial form for the pharmaceutical applications.

Supplementary Information The online version contains supplementary material available at https://doi.org/10.1007/s11240-021-02154-8.

Authors contribution MD: Conceptualization, Investigation, Data curation, Writing - Original draft preparation. KSŁ: Conceptualization, Data curation, Writing-Reviewing and Editing. MS: Methodology, Data curation. AA: Writing-Reviewing and Editing. KW: Supervision, Reviewing and Editing.

Funding This work was funded by the Polish National Centre of Research and Development (Grant No. PBS2/A8/23/2013).

\section{Declarations}

Conflict of interest The authors declare that they had no conflict of interest.

Open Access This article is licensed under a Creative Commons Attribution 4.0 International License, which permits use, sharing, adaptation, distribution and reproduction in any medium or format, as long as you give appropriate credit to the original author(s) and the source, provide a link to the Creative Commons licence, and indicate if changes were made. The images or other third party material in this article are included in the article's Creative Commons licence, unless indicated otherwise in a credit line to the material. If material is not included in the article's Creative Commons licence and your intended use is not permitted by statutory regulation or exceeds the permitted use, you will need to obtain permission directly from the copyright holder. To view a copy of this licence, visit http://creativecommons.org/licenses/by/4.0/.

\section{References}

Adamczak A, Dreger M, Seidler-Łożykowska K, Wielgus K (2019) Fireweed (Epilobium angustifolium L.): botany, phytochemistry and traditional uses. A Review. Herba Pol 65:51-63. https://doi. org/10.2478/hepo-2019-0018

Anstett DN, Cheval I, D'Souza C et al (2019) Ellagitannins from the Onagraceae decrease the performance of generalist and specialist 
herbivores. J Chem Ecol 45:86-94. https://doi.org/10.1007/ s10886-018-1038-x

Baert N, Karonen M, Salminen JP (2015) Isolation, characterisation and quantification of the main oligomeric macrocyclic ellagitannins in Epilobium angustifolium by ultra-high performance chromatography with diode array detection and electrospray tandem mass spectrometry. J Chromatogr A 1419:26-36. https://doi.org/ 10.1016/j.chroma.2015.09.050

Baert N, Kim J, Karonen M, Salminen JP (2017a) Inter-population and inter-organ distribution of the main polyphenolic compounds of Epilobium angustifolium. Phytochemistry 134:54-63. https://doi. org/10.1016/j.phytochem.2016.11.003

Baral S, Pariyar R, Kim J et al (2017b) Quercetin-3-O-glucuronide promotes the proliferation and migration of neural stem cells. Neurobiol Aging 52:39-52. https://doi.org/10.1016/j.neurobiola ging.2016.12.024

Bazylko A, Kiss AK, Kowalski J (2007) High-performance thinlayer chromatography method for quantitative determination of oenothein B and quercetin glucuronide in aqueous extract of Epilobii angustifolii herba. J Chromatogr A 1173(1-2):146150. https://doi.org/10.1016/j.chroma.2007.10.019

Cardoso JC, de Oliveira MEB, Cardoso FDC (2019) Advances and challenges on the in vitro production of secondary metabolites from medicinal plants. Hortic Brasileira 37:124-132. https:// doi.org/10.1590/s0102-053620190201

Deng LQ, Zhou SY, Mao JX et al (2018) HPLC-ESI-MS/MS analysis of phenolics and in vitro antioxidant activity of Epilobium angustifolium L. Nat Prod Res 32:1432-1435. https://doi.org/10.1080/ 14786419.2017.1344659

Deng L, Zong W, Tao X et al (2019) Evaluation of the therapeutic effect against benign prostatic hyperplasia and the active constituents from Epilobium angustifolium L. J Ethnopharmacol 232:1-10. https://doi.org/10.1016/j.jep.2018.11.045

Dreger M, Wegenke J, Makowiecka J et al (2016) Application of multishoots cultures in micropropagation of willow herb (Chamaenerion angustifolium (L.) Scop.). Herba Polonica 62:28-39. https:// doi.org/10.1515/hepo-2016-0015

Dreger M, Gryszczyńska A, Szalata M, Wielgus K (2020) Micropropagation and HPLC-DAD, UPLC MS/MS analysis of oenothein $\mathrm{B}$ and phenolic acids in shoot cultures and in regenerated plants of fireweed (Chamerion angustifolium (L.) Holub). Plant Cell Tiss Organ Cult 143:653-663. https://doi.org/10.1007/ s11240-020-01949-5

Ducrey B, Marston A, Göhring S et al (1997) Inhibition of $5 \alpha$-Reductase and Aromatase by the Ellagitannins Oenothein $\mathrm{A}$ and Oenothein B from Epilobium Species. Planta Med 63(2):111-114

Esposito C, Santarcangelo C, Masselli R et al (2021) Epilobium angustifolium L. extract with high content in oenothein B on benign prostatic hyperplasia: a monocentric, randomized, double-blind, placebo-controlled clinical trial. Biomed Pharmacother 138:111414. https://doi.org/10.1016/j.biopha.2021.111414

European Medicines Agency (2015) European Union herbal monograph on Epilobium angustifolium L. and / or Epilobium parviflorum Schreb., herba. https://www.ema.europa.eu/en/medicines/ herbal/epilobii-herba. Accessed 26.03.2021

Garcia-Muñoz C, Vaillant F (2014) Metabolic fate of ellagitannins: implications for health, and research perspectives for innovative functional foods. Crit Rev Food Sci Nutr 54(12):1584-1598. https://doi.org/10.1080/10408398.2011.644643

García-Villalba R, Giménez-Bastida JA, Ávila-Gálvez MA, et al. (2020). Ellagitannins and their gut microbiota-derived metabolites: urolithins. In: Tomás-Barberán FA, González-Sarrías A, García-Villalba R (eds) Dietary polyphenols. https://doi.org/10. 1002/9781119563754.ch9
Granica S, Bazylko A, Kiss AK (2012) Determination of macrocyclic ellagitannin oenothein B in plant materials by HPLC-DAD-MS: method development and validation. Phytochem Anal 23(6):582587. https://doi.org/10.1002/pca.2358

Granica S, Piwowarski JP, Czerwińska ME, Kiss AK (2014) Phytochemistry, pharmacology and traditional uses of different Epilobium species (Onagraceae): a review. J Ethnopharmacol 156:316346. https://doi.org/10.1016/j.jep.2014.08.036

Gryszczyńska A, Dreger M, Piasecka A et al (2018) Qualitative and quantitative analyses of bioactive compounds from ex vitro Chamaenerion angustifolium (L.) (Epilobium augustifolium) herb in different harvest times. Ind Crops Prod 123:208-220. https:// doi.org/10.1016/j.indcrop.2018.06.010

Hatano T, Kusuda M, Inada K et al (2005) Effects of tannins and related polyphenols on methicillin-resistant Staphylococcus aureus. Phytochemistry 66:2047-2055. https://doi.org/10.1016/j.phytochem. 2005.01.013

He J, Yang W, Cheng B et al (2020) Integrated metabolomic and transcriptomic profiling reveals the tissue-specific flavonoid compositions and their biosynthesis pathways in Ziziphora bungeana. Chinese Med (united Kingdom) 15:1-15. https://doi.org/10.1186/ s13020-020-00354-6

Hevesi Tóth B, Blazics B, Kéry Á (2009) Polyphenol composition and antioxidant capacity of Epilobium species. J Pharm Biomed Anal 49:26-31. https://doi.org/10.1016/j.jpba.2008.09.047

Hiermann A, Reidlinger M, Juan H, Sametz W (1991) Isolierung des antiphlogistischen Wirkprinzips von Epilobium angustifolium. Planta Med 57:357-360. https://doi.org/10.1055/s-2006-960117

Hiermann A, Schramm HW, Laufer S (1998) Anti-inflammatory activity of myricetin-3-O- $\beta$-D-glucuronide and related compounds. Inflamm Res 47:421-427. https://doi.org/10.1007/s000110050355

Ishisaka A, Mukai R, Terao J et al (2014) Specific localization of quercetin-3-O-glucuronide in human brain. Arch Biochem Biophys 557:11-17. https://doi.org/10.1016/j.abb.2014.05.025

Jürgenson S, Matto V, Raal A (2012) Vegetational variation of phenolic compounds in Epilobium angustifolium. Nat Prod Res 26:19511953. https://doi.org/10.1080/14786419.2011.643310

Kalle R, Belichenko O, Kuznetsova N et al (2020) Gaining momentum: popularization of Epilobium angustifolium as food and recreational tea on the Eastern edge of Europe. Appetite. https://doi.org/ 10.1016/j.appet.2020.104638

Kaškoniene V, Stankevičius M, Drevinskas T et al (2015) Evaluation of phytochemical composition of fresh and dried raw material of introduced Chamerion angustifolium L. using chromatographic, spectrophotometric and chemometric techniques. Phytochemistry 115:184-193. https://doi.org/10.1016/j.phytochem.2015.02.005

Kiss AK, Bazylko A, Filipek A et al (2011) Oenothein B's contribution to the anti-inflammatory and antioxidant activity of Epilobium sp. Phytomedicine 18:557-560. https://doi.org/10.1016/j.phymed. 2010.10.016

Kumari A, Baskaran P, Plačková L et al (2018) Plant growth regulator interactions in physiological processes for controlling plant regeneration and in vitro development of Tulbaghia simmleri. J Plant Physiol 223:65-71. https://doi.org/10.1016/j.jplph.2018.01.005

Li L, Liu M, Shi K et al (2019) Dynamic changes in metabolite accumulation and the transcriptome during leaf growth and development in Eucommia ulmoides. Int J Mol Sci. https://doi.org/10. 3390/ijms20164030

Mamaní A, Filippone MP, Grellet C et al (2012) Pathogen-induced accumulation of an ellagitannin elicits plant defense response. Mol Plant-Microbe Interact 25:1430-1439. https://doi.org/10. 1094/MPMI-12-11-0306

Martos GG, Tomas Grau RH, Marino C et al (2020) Defense elicitation activity of the ellagitannin HeT depends on its redox state. Sci Hortic 267:109312. https://doi.org/10.1016/j.scienta.2020.109312 
Maruška A, Ragažinskiene O, Vyšniauskas O et al (2014) Flavonoids of willow herb (Chamerion angustifolium (L.) Holub) and their radical scavenging activity during vegetation. Adv Med Sci 59:136-141. https://doi.org/10.1016/j.advms.2013.10.002

Moilanen J, Karonen M, Tähtinen P et al (2016) Biological activity of ellagitannins: effects as anti-oxidants, pro-oxidants and metal chelators. Phytochemistry 125:65-72. https://doi.org/10.1016/j. phytochem.2016.02.008

Mondolot L, La Fisca P, Buatois B et al (2006) Evolution in caffeoylquinic acid content and histolocalization during Coffea canephora leaf development. Ann Bot 98:33-40. https://doi.org/ 10.1093/aob/mcl080

Monschein M, Jaindl K, Buzimkić S, Bucar F (2015) Content of phenolic compounds in wild populations of Epilobium angustifolium growing at different altitudes. Pharm Biol 53:1576-1582. https:// doi.org/10.3109/13880209.2014.993039

Murashige T, Skoog F (1962) A revised medium for rapid growth and bioassays with tobacco tissue cultures. Physiol Plantarum 15:473-497. https://doi.org/10.1111/j.1399-3054.1962.tb08052.x

Pandey S, Patel P, Prasad A et al (2020) Assessment of direct shoot organogenesis and genetic fidelity in Solanum viarum Dunal-a commercially important medicinal plant. Vitr Cell Dev Biol Plant 56:538-547. https://doi.org/10.1007/s11627-020-10073-0

Petrụlová V, Dučaiová Z, Repčák M, (2014) Short-term UV-B dose stimulates production of protective metabolites in Matricaria chamomilla Leaves. Photochem Photobiol 90:1061-1068. https:// doi.org/10.1111/php. 12300

Ruszová E, Cheel J, Pávek S et al (2013) Epilobium angustifolium extract demonstrates multiple effects on dermal fibroblasts in vitro and skin photo-protection in vivo. Gen Physiol Biophys 32(3):347-359. https://doi.org/10.4149/gpb_2013031

Rutkowska M, Balcerczak E, Świechowski R et al (2020) Seasonal variation in phenylpropanoid biosynthesis and in vitro antioxidant activity of Sorbus domestica leaves: harvesting time optimisation for medicinal application. Ind Crops Prod 156:112858. https://doi. org/10.1016/j.indcrop.2020.112858

Schepetkin IA, Ramstead AG, Kirpotina LN et al (2016) Therapeutic potential of polyphenols from Epilobium Angustifolium (Fireweed). Phyther Res 30:1287-1297. https://doi.org/10.1002/ptr. 5648

Sõukand R, Mattalia G, Kolosova V et al (2020) Inventing a herbal tradition: the complex roots of the current popularity of Epilobium angustifolium in Eastern Europe. J Ethnopharmacol. https://doi. org/10.1016/j.jep.2019.112254

Stolarczyk M, Naruszewicz M, Kiss AK (2013) Extracts from Epilobium $\mathrm{sp}$. herbs induce apoptosis in human hormone-dependent prostate cancer cells by activating the mitochondrial pathway. J Pharm Pharmacol 65:1044-1054. https://doi.org/10.1111/jphp. 12063

Tajner-Czopek A, Gertchen M, Rytel E et al (2020) Study of antioxidant activity of some medicinal plants having high content of caffeic acid derivatives. Antioxidants 9(5):412. https://doi.org/10. 3390/antiox9050412

Turker AU, Mutlu EC, Yidirim AB (2008) Efficient in vitro regeneration of fireweed, a medicinal plant. Acta Physiol Plant 30:421426. https://doi.org/10.1007/s11738-008-0136-8

Vitalone A, Bordi F, Baldazzi C et al (2001) Anti-proliferative effect on a prostatic epithelial cell line (PZ-HPV-7) by Epilobium angustifolium L. Il Farmaco 56(5-7):483-489. https://doi.org/10.1016/ S0014-827X(01)01067-9

Vitalone A, Allkanjari O (2018) Epilobium spp: pharmacology and phytochemistry. Phytother Res 32:1229-1240. https://doi.org/10. 1002/ptr.6072

Wagner WL, Hoch PC, Raven PH (2007) Revised classification of the Onagraceae. Syst Bot Monogr 83:1-240

Yoshida T, Yoshimura M, Amakura Y (2018) Chemical and biological significance of oenothein B and related ellagitannin oligomers with macrocyclic structure. Molecules 23:1-21. https://doi.org/ $10.3390 /$ molecules 23030552

Yuan Y, Zhang J, Liu X et al (2020) Tissue-specific transcriptome for Dendrobium officinale reveals genes involved in flavonoid biosynthesis. Genomics 112:1781-1794. https://doi.org/10.1016/j. ygeno.2019.10.010

Zimik M, Arumugam N (2017) Induction of shoot regeneration in cotyledon explants of the oilseed crop Sesamum indicum L. J Genet Eng Biotechnol 15:303-308. https://doi.org/10.1016/j.jgeb.2017. 07.006

Publisher's Note Springer Nature remains neutral with regard to jurisdictional claims in published maps and institutional affiliations. 